\title{
Discovery of a Lochkovian flora (Lower Devonian) in the Iberian Peninsula
}

\author{
Borja CASCALES-MIÑANA \\ Department of Plant Biology, University of Valencia, \\ Av. Vicente Andrés Estellés $\mathrm{s} / \mathrm{n}$, \\ SP-46100 Burjasot, Valencia (Spain) \\ borja.cascales@uv.es \\ Carlos MARTíNEZ-PÉREZ \\ Héctor BOTELLA \\ Department of Geology, University of Valencia, \\ C. Doctor Moliner 50, SP-46100, Burjassot, Valencia (Spain) \\ carlos.martinez-perez@uv.es \\ hector.botella@uv.es
}

KEY WORDS

Lower Devonian,

Lochkovian,

Taeniocrada-like stems,

Spain.
MOTS CLÉS

Dévonien inférieur,

Lochkovien,

tiges de type

Taeniocrada,

Espagne.
Cascales-Miñana B., Martínez-Pérez C. \& Botella H. 2011. - Discovery of a Lochkovian flora (Lower Devonian) in the Iberian Peninsula. Geodiversitas 33 (1): 33-41. DOI: 10.5252/ g2011n1a3.

\begin{abstract}
The Lower Devonian represents an important episode in plant life history, which was marked by the diversification of land plants. Unfortunately, remains of early Devonian plants in the Iberian Peninsula are scarce. In the present paper, we describe a small assemblage of early land plants from the Lochkovian (Lower Devonian) of the Teruel Province in Spain. The main element consists of Taeniocrada-like sterile stems that are predominantly dichotomous and ribbon-like with a narrow central strand. An unidentified fossil formed by dichotomous axes together with an uncertain globular structure were also observed. This finding increases our knowledge of the palaeogeographical distribution of early land plants.
\end{abstract}

\section{RÉSUMÉ}

Découverte d'une paléoflore lochkovienne (Dévonien inférieur) dans la péninsule ibérique.

Le Dévonien Inférieur représente un épisode important dans l'histoire de la vie des plantes, marqué par une diversification importante des végétaux terrestres. Malheureusement, les restes de plantes dévoniennes primitives de la péninsule Ibérique sont rares. Dans cet article, nous décrivons un nouvel assemblage de plantes du Lochkovien (Dévonien Inférieur) de la Province de Teruel en Espagne. Les restes majoritaires qui consistent en branches stériles de type Taeniocrada sont dichotomes et rubannés, avec un faisceau central étroit. Un autre type de macrofossile non identifié présentant des axes dichotomiques ainsi qu'une structure globulaire est également observé. Cette découverte précise notre connaissance sur la distribution paléogéographique des premières plantes terrestres. 


\section{INTRODUCTION}

During Late Silurian and Early Devonian times, land plants underwent rapid primary diversification, being one of the most critical episodes in the embryophytic life history (Kenrick \& Crane 1997). Soon afterwards, land vegetation diversified rapidly from these primitive rhyniophyte and lycophyte precursors. In this context, the Early Devonian represents the first step in this process. Unfortunately, the fossil record of early land plants is scarce and shows substantial taphonomic bias. Thus, any new data concerning the diversity, morphology and geographical distribution of early land plants are important to increase our understanding of their early evolution and diversification.

In recent years, numerous papers based on Early Devonian flora have been published (Edwards et al. 2001; Gerrienne et al. 2001, 2006; MeyerBerthaud \& Gerrienne 2001; Wang \& Hao 2002; Wang et al. 2003a, b; Rubinstein et al. 2005). Nevertheless, such studies are scarce on the Iberian Peninsula, due to the fact that the plant remains are usually associated with marine environments, and are highly fragmentary, poorly preserved and difficult to identify.

Here we describe new plant macrofossil remains from the late Lochkovian (Lower Devonian) from Spain. Taking into consideration the palaeogeographical position of Spain during Lochkovian times, with the Armorica palaeoblock belonging to the peri-Gondwana or Gondwana-derived terranes, and also the fact that the Gondwana plant record is notoriously incomplete for this geological stage, we believe that the material described here provides useful information. This information about the diversity, morphology and geographical distribution of plants during the Early Devonian increases our understanding of their early evolution and diversification.

\section{GEOLOGICAL SETTING}

The plant remains studied herein were recovered from Section South Barranco Santo Domingo locality, $2.3 \mathrm{~km} \mathrm{SW}$ of the small village of Mezquita de Loscos (Province of Teruel, Spain) in the southeastern part of the Iberian Chains (Fig. 1). This locality is situated within the so-called Axial Depression of the Río Cámaras (Carls 1988), which includes outcrops from the Pridoli (Silurian) to the Famenian (Upper Devonian) that are not exposed in a complete sequence, but are found in numerous short sections.

Nine geological formations have been identified in the Lower Devonian strata of this area. They are, in stratigraphic order: the Luesma, Nogueras, Santa Cruz, Mariposas, Castellar, Ramblar, Loscos, Peña Negra and Molino. Section South Barranco Santo Domingo (Fig. 1C) shows strata (units $\mathrm{d} 2 \mathrm{a} \beta 5$ to $\mathrm{d} 2 \mathrm{~b} \alpha 3$ ) of the Nogueras Formation (Lochkovian-Pragian), which consist of $140 \mathrm{~m}$ of shallow-water marine deposits with bioclastic limestones, marls and arenaceous shales; a few sand lenses (palaeochannels) or thin sand beds are interbedded between the shales. This formation includes the "Leitbank A" (Bed A), a laterally continuous dark mudstone bed, $35-50 \mathrm{~cm}$ thick, which corresponds almost exactly to the Lochkovian/Pragian boundary. The most important biostratigraphic marker found in this Bed A is the brachiopod Vandercammenina sollei, which indicates the beginning of the Pragian in Rhenish facies (Carls \& Valenzuela-Ríos 2002). Plant remains occur in unit $\mathrm{d} 2 \mathrm{~b} \alpha$, approximately $10 \mathrm{~m}$ below the Lochkovian/Pragian boundary (Bed A, see Fig. 1D). The study of fossil brachiopods, conodonts (Carls 1999), fish microremains (Wang 1993; Botella \& Valenzuela-Ríos 2002; Carls \& Valenzuela-Ríos 2002; Botella et al. 2006) and ostracods (Dojen 2005) from this unit also confirmed a late Lockhovian age. For a recent detailed geological and stratigraphic description of the ADCR (Axial Depression in the Rio Cámaras River) area, see Carls \& Valenzuela-Ríos (2002), and a detailed faunal succession of the Nogueras Formation, is given by Carls (1999).

\section{MATERIAL AND METHODS}

All specimens are preserved as coalified compressions and impressions in yellowish marly sandstone 

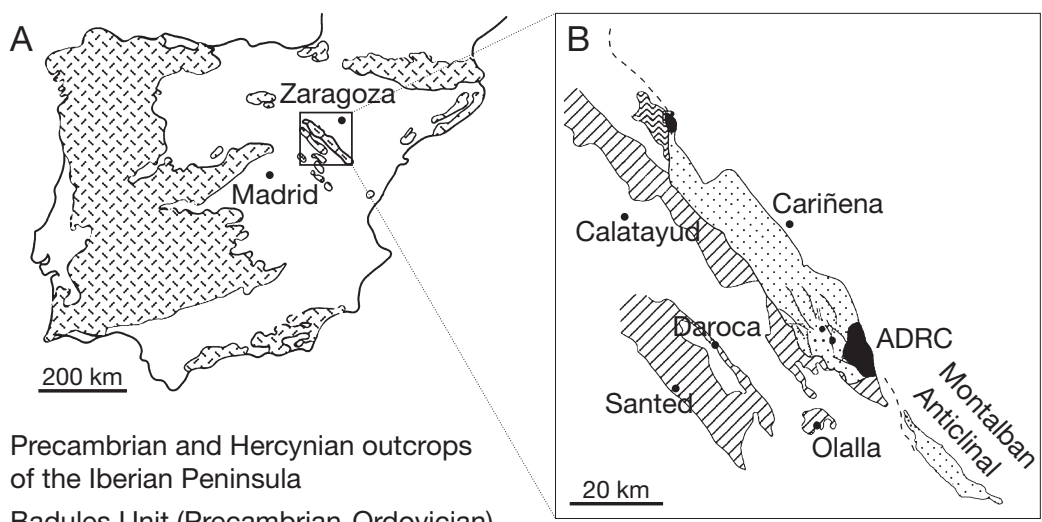

Precambrian and Hercynian outcrops of the Iberian Peninsula

$\square 7$ Badules Unit (Precambrian-Ordovician)

Herrera Unit (Upper Cambrian-Devonian)

Mesones Unit (Lower-Middle Cambrian)
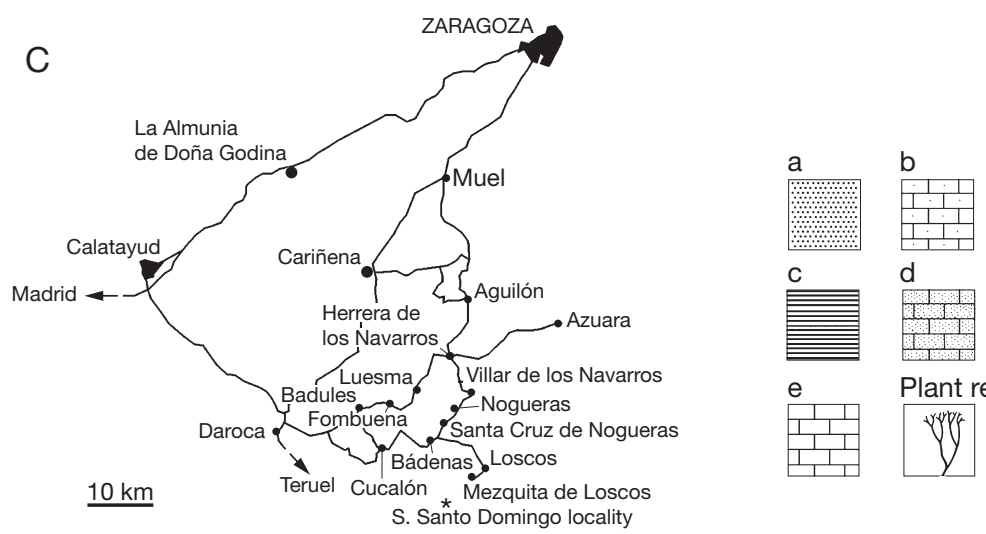

Plant remains
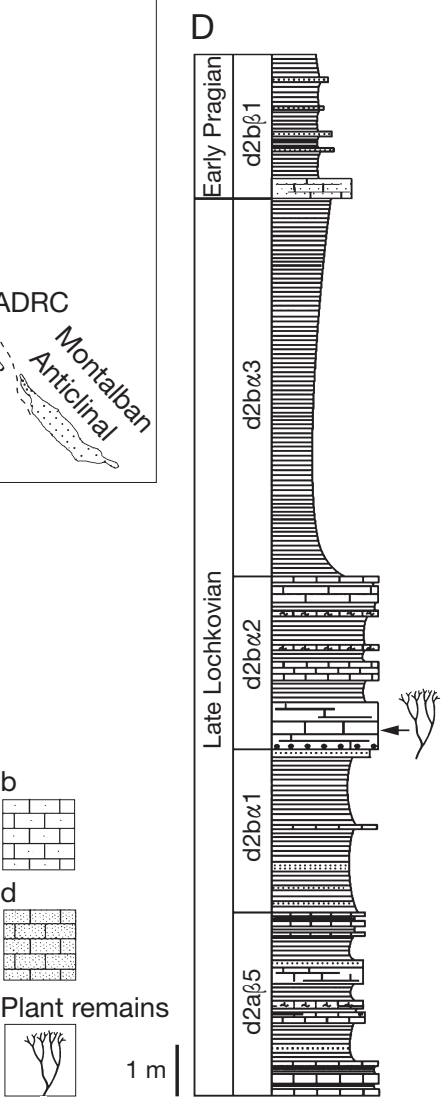

FIG. 1. - Localization and geological context of the fossil assemblage: A, geological setting of the studied area with an indication of the distribution of Precambrian and Palaeozoic rocks on the Iberian Peninsula; B, geological map of the Palaeozoic outcrops in the Iberian chains. The study area, indicated in black, is the Axial Depression of the Río Cámaras River (ADRC); C, geographical setting of the studied area with the position of the South Santo Domingo Locality; D, stratigraphic column with indications of the level of plant remains (adapted from Dojen 2005); a, sandstones; b, marly limestones; c, shales; d, sandy limestones; e, limestones.

(Fig. 2A). Since very little material is available, no chemical treatment was used to prepare the specimens. Parts and counterparts of the samples were observed using a Leica Wild M3B light microscope, and they were photographed with a JVC TK-1280E digital camera. The new material described herein consists of eight specimens on a single slab of rock with one part (Fig. 2A) and two counterparts (Fig. 2B, C). This material is deposited at the Fundación Conjunto Paleontológico de Teruel-Dinópolis (Teruel, Spain) (CPT-4320).

\section{ASSEMBLAGE DESCRIPTION}

The branching of axes is dichotomous and seems to follow a pseudomonopodial pattern (Fig. 3). The remains also include ribbon-like axes with a narrow central conducting strand (Fig. 3A, B). The fossil axes often show characteristic folding and longitudinal wrinkling. The flattened stems with a marked central strand appear to form a mat of compressed plant remains. The width of the main axis is $2.5 \mathrm{~mm}$ with a typical deviation of $0.09 \mathrm{~mm}$ (Fig. 3C). The preserved length of the longest main axis is approximately $87 \mathrm{~mm}$. The lateral axes are 

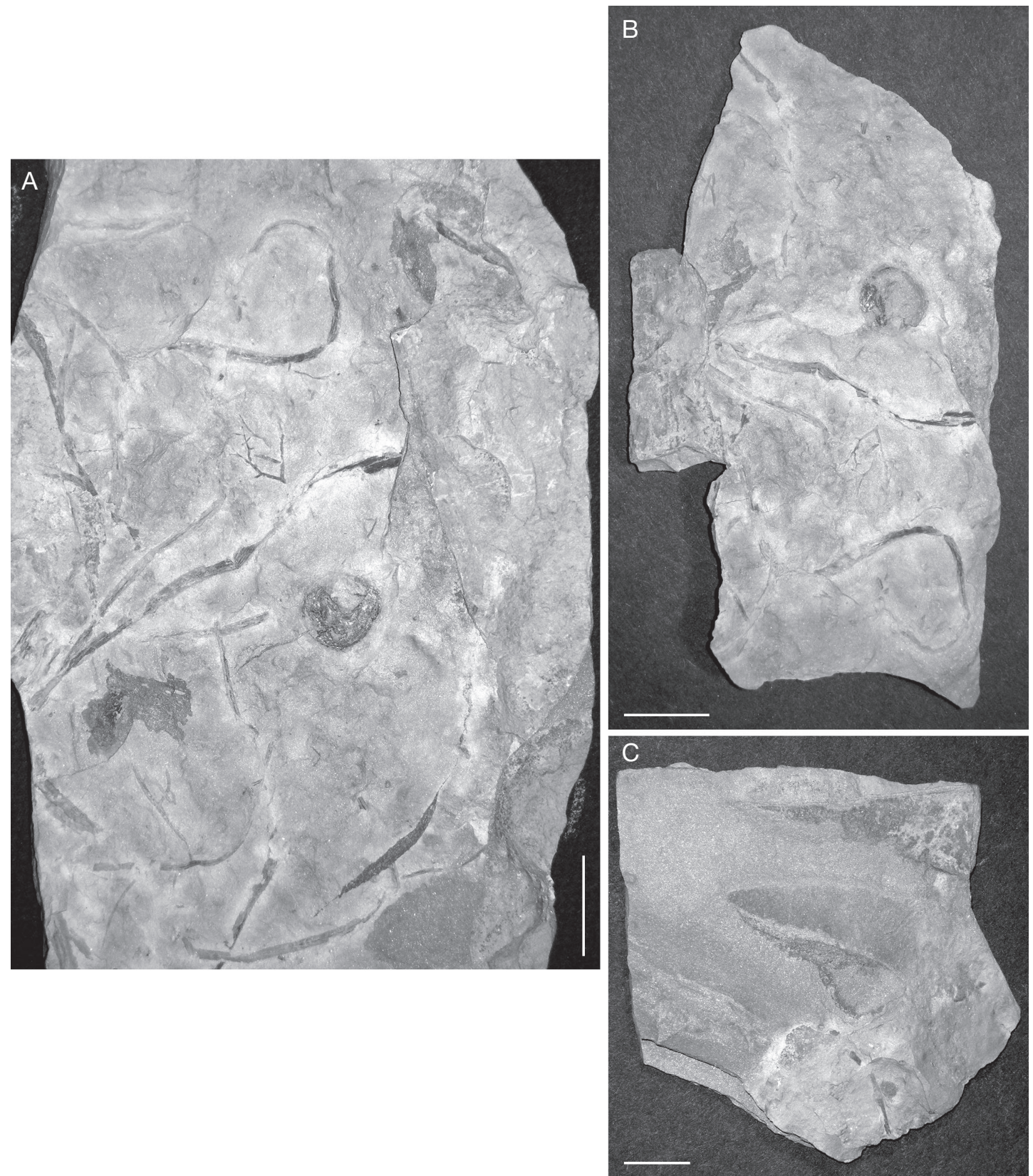

FIG. 2. - Plant macrofossil remains from the Iberian Peninsula: A, general view of the studied material (sample CPT-4320); B, counterpart 1; C, counterpart 2. Scale bars: A, $25 \mathrm{~mm}$; B, C, $20 \mathrm{~mm}$.

inserted on the main axis with an angle ranging from 25 to 65 degrees. The main axes are slightly curved. Successive lateral axes are borne alternately on the main axis (Fig. 3A). The smallest axes are poorly preserved, and are usually fragmentary (Fig. 3DF). The estimated distance between the branching 

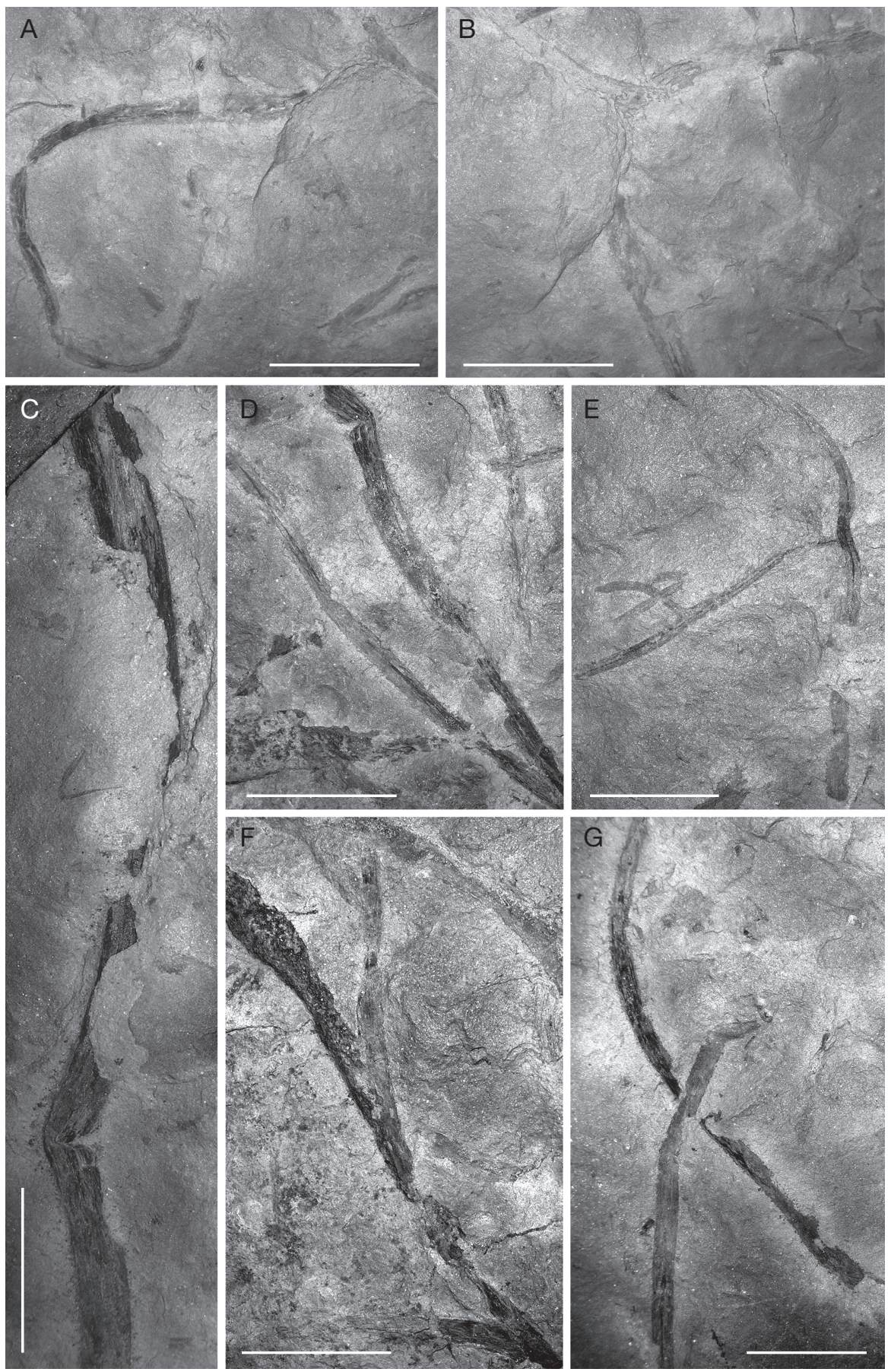

FIG. 3. - Morphology of stems and branching pattern (CPT-4320) of Taeniocrada-like stems: A, basal stem, slightly curved; B, bifurcation of stems; C, the principal axes of the specimen; $\mathbf{D}$, possible basal stems; $\mathbf{E}$, dichotomous branching pattern; $\mathbf{F}$, morphology of stems and branching; G, possible basal rhizomatous axis. Scale bars: A, B, 15 mm; C-G, $10 \mathrm{~mm}$. 
points along these axes is $27 \mathrm{~mm}$. Circinate vernation was not observed. These remains do not show any associated sporangium. The fossils are tentatively identified as Taeniocrada sp.

The only possible sporangium in the sample is constituted by a round body (Fig. 4A). The level of conservation of the material shows that this structure was borne laterally. Unfortunately, the round body does not present clear evidence of attachment to the stems. This body measures $5 \times 4 \mathrm{~mm}$. The dehiscence line cannot be evaluated, nor the distance between consecutive similar structures. Spores were not observed.

A dichotomous axis system and a globular body, part and counterpart (Fig. 4B-E) are also visible in the sample. The dichotomous specimen is $28 \mathrm{~mm}$ long and the whole system is approximately $24 \mathrm{~mm}$ wide. The ramification angle ranges from 70 to 45 degrees (Fig. 4D, E). This globular structure is $15 \times 12 \mathrm{~mm}$ across (Fig. 4B).

\section{DISCUSSION}

The Early Devonian was a key moment in plant life history (Gensel \& Andrews 1984; Raymond 1987; Meyer-Berthaud \& Gerrienne 2001). Among the primitive forms of vascular plants present during this important geological period, one of the more relevant groups was formed by the paraphyletic group of the rhyniophytes. The members of this group, from a general viewpoint, consist of: 1) simple axes with a cuticle, stomata, epidermis, cortex and a terete (circular) centrarch xylem (xylem development occurs from the centre of the stem to the periphery), without well-developed appendages or roots; 2) simple, isotomous branching systems to anisotomous, dichotomous, pseudomonopodial systems with up to four or five orders of branching, whole plants rarely exceeding ten centimetres; 3) sporangia globose to almost reniform (kidneyshaped) with longitudinal dehiscence; and 4) spores with sporopolleinin and distinct trilete marks on the proximal side from their placement in the tetrad (Stewart \& Rothwell 1993; Taylor \& Taylor 1993; Cleal \& Thomas 1994, 1999; Roth-Nebelsick et al. 2000; Wellman et al. 2006). This group encompasses the better-known primitive plants but also a group of taxa that are taxonomically controversial: the Taeniocrada-like plants. Taeniocrada is not considered to be a natural genus (Hueber 1982; Taylor 1986) but a form genus for sterile ribbon-like axes with a narrow central conducting strand, typically found in early Devonian (Lochkovian) rocks (Fanning et al. 1992).

As indicated above, the plant fossil assemblage described here is constituted by a main group of stems and an isolated round body, with an associated small dichotomous structure. The fragmentary nature of the assemblage as well as the depositional conditions in high-energy coastal environments suggests that these plant remains are allochthonous and apparently underwent significant transport. Thus, in our opinion, they represent a heterogeneous assemblage, rather than a basal mass of stems with only a few associated round bodies and small dichotomous vegetative structures from diverse organisms.

The general features present in the main group of stems in our specimens are consistent with many of the general characteristics of the genus Taeniocrada. The presence of dichotomous stems with ribbon and flattened-like axes (Fig. 3B, E, F) supports the assignation of these remains to Taeniocradalike stems. Thus, our main remains, constituted by a mass of sterile axes of flattened stems, could be interpreted as a mass of Taeniocrada-like stems with bifurcation. Moreover, the flattened stems with the median crest agree with the description of the form-genus Taeniocrada with long ribbonlike axes, with a clear midrib (the remainder of the central strand). On the other hand, we do not have direct and irrefutable evidence of their vascularity, due to the impossibility of observing whether the central line is constituted by tracheids of the S-type (as in the Rhyniopsida) or another type, and thus we cannot categorically assign our remains to this group of early vascular land plants. In addition, the three-dimensionality or otherwise of the branching systems and the number of branching orders are not evident in our material.

Independently of the sterile axis and the round and globular structures presented, unidentified dichotomous axes are also present in the sample 

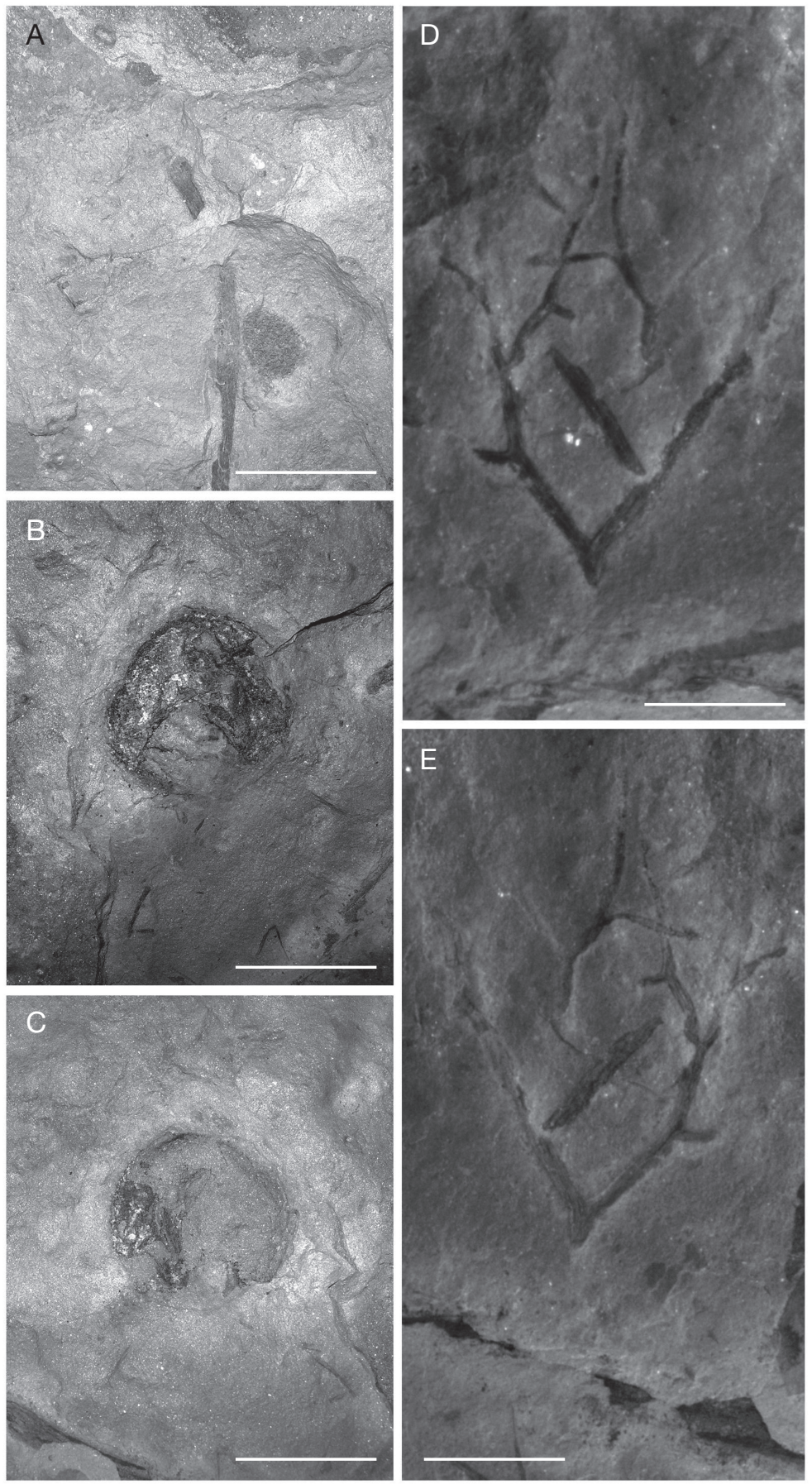

FIG. 4. - Globular structures and unidentified dichotomous axes in CPT-4320I: A, round structure, counterpart 2, small specimen with a round body in the lateral view; B, unresolved globular structure; C, counterpart 1, globular body with apparently thick border; $\mathbf{D}$, uncertain dichotomous vegetative structure; E, counterpart 1, dichotomous branching. Scale bars: A, D, E, 10 mm; B, C, 12 mm. 
(Fig. 4D, E). These controversial remains cannot be taxonomically resolved because the reproductive bodies are vital for their classification in these early vascular plants. Nevertheless, although several hypotheses can be proposed, we believe that these remains are in concordance with all Devonian remains present in the sample. Although the fossil record of Lower Devonian land plants is limited and present outcrops are not homogeneously distributed, every year, new findings increase our knowledge of these early terrestrial floras from a taxonomic, evolutionary and palaeogeographic viewpoint. With regards the latter, the macrofossil evidence of early vascular plants from Spain presented here, which is extremely rare, increases the palaeogeographic knowledge of this heterogeneous and emblematic group and proves the distribution of this early floras in Peri-Gondwana or Gondwana derivated terrains during early Devonian times.

Finally, special attention should be given to the temporal aspect of these Lochkovian remains on the Iberian Peninsula. During the 1970s, several authors mentioned indeterminable plant remains of presumed Silurian age (Teixeira 1970; Martínez García 1972). The age of these indeterminate remains was subsequently altered and they were finally assigned to the Late Devonian or Mississippian (Teixeira \& Paris 1973). A recent study on Devonian vascular plants from the Iberian Peninsula gave a summary of this important record, pointing out that the old well-known findings of Devonian vascular plants comes not early than the Emsian (Montero 2008). In a recent revision, it can be seen that the oldest plant remains of the Iberian Peninsula were collected from the Gedinian sediments of Monterrubia de la Serena (Montero \& Dieguez 2010). These remains were assigned to Sciadophyton steinmanni Kräusel \& Weyland by Álvarez-Ramis (1995). Nevertheless, although Montero \& Dieguez (2010) mentioned in their work this Devonian reference, this material has not been re-studied and their assignment to vascular plant remains should be revised according to the actual stage of knowledge. This fact provides a crucial temporal character of this discovery. In addition, from Montero \& Dieguez (2010) it can be inferred that the oldest plant remains assigned to Taeniocrada sp. are temporally placed in the Middle
Devonian, and thus the Taeniocrada plant remains presented herein from the Lochkovian represent a significant addition to Iberian palaeobotany.

\section{Acknowledgements}

We would like to extend special thanks to Brigitte Meyer-Berthaud (Unité mixte de recherche en Botanique et Bioinformatique de l'Architecture des Plantes, CIRAD, France) and an anonymous reviewer, who kindly reviewed the scientific content of this paper. Her comments and corrections substantially improved an earlier version of this manuscript. We also thank José B. Diez (Departamento de Xeociencias Mariñas e Ordenación do Territorio, Universidade de Vigo, Spain) and Antoine Bercovici (CNRS Géosciences Rennes, Université de Rennes, France) for their support regarding corrections of the French language. This work was partially supported by a FPU Research Fellowship from the Spanish Ministry of Education and Science and by the Instituto de Estudios Turolenses.

\section{REFERENCES}

Álvarez-Ramis C. 1995. - Presencia de Sciadophyton teinmann en el Devónico inferior de las series de Monterrubio de la Serena (Badajoz, España). Coloquios de Paleontología 47: 145-150.

Botella H. \& VAlenZuela-Ríos J. I. 2002. — Análisis comparativo de microinvertebrados fósiles del límite Lochkoviense/Pragiense (Devónico Inferior) en la Depresión Axial del río Cámaras. Teruel 88: 45-68.

Botella H., Valenzuela-Ríos J. I. \& Carls P. 2006. A new Early Devonian thelodont from Celtiberia (Spain); with a revision of Spanish thelodonts. Palaeontology 49: 141-154.

CARLS P. 1988. - The Devonian of Celtiberia (Spain) and Devonian paleogeography of SW Europe, in McMillan N. J., EmbrY A. F. \& Glass D. J. (eds), Devonian of the World Memoir of the Canadian Society of Petroleum Geologist 14, Calgary: 421-266.

CARLS P. 1999. - El Devónico de Celtiberia y sus fósiles, in Vintaned J. A. \& Liñan E. (eds), Memorias de las VI Jornadas Aragonesas de Paleontología (25 años de Paleontología Aragonesa, Homenaje al Prof. Leandro Sequeiros). Instituto Fernando el Católico, Zaragoza: 101-164.

Carls P. \& VAlenZuela-Ríos J. I. 2002. — DevonianCarboniferous rocks from the Iberian Cordillera, 
in García-López S. \& Bastida F. (eds), Palaeozoic Conodonts from Northern Spain. Instituto Geológico y Minero de España, Serie Cuadernos del Museo Geominero, Madrid: 299-314.

Cleal C. J. \& Thomas B. A. 1994. - Palaeozoic Palaeobotany of Great Britain. Chapman and Hall, London, $312 \mathrm{p}$.

Cleal C. J. \& Thomas B. A. 1999. - Plant Fossils: the History of Land and Vegetation. The Boydell Press, Woodbridge, $128 \mathrm{p}$.

Dojen C. 2005. - Early Devonian Ostracods of Celtiberia (NE Spain) Taxonomy, Palaeoecology, Biostratigraphy, and Bioeography. Technische Universität, Braunsweig, $256 \mathrm{p}$.

Edwards D., Morel E., Poire D. G. \& Cingolani C. A. 2001. - Land plants in the Devonian Villavicencio Formation, Mendoza Province, Argentina. Review of Palaeobotany and Palynology 116: 1-18.

FANNING U., EDWARDS D. \& RiCHARDSON J. B. 1992. A diverse assemblage of early land plants from the Lower Devonian of the Welsh Borderland. Botanical Journal of the Linnean Society 109: 161-188.

Gensel P. G. \& ANDREWs H. N. 1984. - Plant Life in the Devonian. Praeger, New York, 381 p.

Gerrienne P., Bergamaschi S., Pereira E., RodRigues M. A. C. \& SteEMANS P. 2001. - An Early Devonian flora, including Cooksonia, from the Parana Basin (Brazil). Review of Palaeobotany and Palynology 116: 19-38.

Gerrienne P., Dilcher D. L., Bergamaschi S., Milagres I., Pereira E. \& Rodrigues M. A. C. 2006. - An exceptional specimen of the early land plant Cooksonia paranensis, and a hypothesis on the life cycle of the earliest eutracheophytes. Review of Palaeobotany and Palynology 142: 123-130.

Hueber F. M. 1982. - Taeniocrada dubia Kr. and W.: its conducting strand of helically strengthened tubes. Botanical Society of America, Miscellaneous series 162: 58-59.

Kenrick P. \& Crane P. R. 1997. - The Origin and Early Diversification of Land Plants: A Cladistic Study. Smithsonian Institution Press, Washington, $441 \mathrm{p}$.

Martínez García E. 1972. - El Silúrico de San Vitero (Zamora). Comparación de series vecinas e importancia orogénica. Acta Geologica Hispanica 7: 104-108.

Meyer-Berthaud B. \& Gerrienne P. 2001. - Aarabia, a new Early Devonian vascular plant from Africa (Morocco). Review of Palaeobotany and Palynology 116: 39-53.

MonTERO A. 2008. - Registros atribuidos a plantas vasculares devónicas en la Península Ibérica. Revista
Española de Paleontología 23: 193-209.

Montero A. \& Dieguez C. 2010. - Devonian floral assemblages and plant megafossils from the Iberian Peninsula: a review. Review of Palaeobotany and Palynology: 162: 231-238.

RAYMOND A. 1987. - Paleogeographic distribution of Early Devonian plant traits. Palaios 2: 113-132.

Roth-Nebelsick A., Grimm G., MosbrugGer V., Hass H. \& KeRP H. 2000. - Morphometric analysis of Rhynia and Asteroxylon: testing functional aspects of early land plant evolution. Paleobiology 26: 405-418.

Rubinstein C., Melo J. H. G. \& Steemans P. 2005. Lochkovian (earliest Devonian) miospores from the Solimoes Basin, northwestern Brazil. Review of Palaeobotany and Palynology 133: 91-113.

SteWART W. N. \& RothWELL G. W. 1993. - Paleobotany and the Evolution of Plants. Cambridge University Press, Cambridge, $521 \mathrm{p}$.

TAYLOR D. W. 1986. - Anatomical and morological study of a new species of Taeniocrada, a Devonian tracheophyte fom New York State. Review of Palaeobotany and Palynology 47: 63-87.

TAYLOR T. N. \& TAYLOR E. L. 1993. - The Biology and Evolution of Fossil Plants. Prentice-Hall, Englewood Cliffs, New Jersey, $982 \mathrm{p}$.

TeIXeIra C. 1970. - Restos vegetais em ftanitos silúricos de Guadramil. Naturália 10: 5.

TeIXeIRA C. \& PARIS J. 1973. - Sobre a presença de Devonico na regiao de Bragança (Guadramil e Mofreita) e de Alcañices (Zamora). Boletim de la Sociedade Geológica de Portugal 18: 199-202.

WANG D. M. \& HAO S. G. 2002. - Guangnania cuneata gen. et sp. nov. from the Lower Devonian of Yunnan Province, China. Review of Palaeobotany and Palynology 122: 13-27.

WANG D. M., HaO S. G. \& WANG Q. 2003a. - Hsua deflexa sp. nov. from the Xujiachong Formation (Lower Devonian) of eastern Yunnan, China. Botanical Journal of the Linnean Society 142: 255-271.

WANG D. M., HaO S. G. \& WANG Q. 2003b. — Tracheid ultrastructure of Hsua deflexa from the Lower Devonian Xujiachong Formation of Yunnan, China. International Journal of Plant Sciences 164: 415-427.

WANG R. 1993. - Taxonomie, Palökologie und Biostratigraphie der Mikroichthyolithen aus dem Unterdevon Keltiberiens, Spanien. Courier Forschungsinstitut Senckenberg 161: 1-205.

Wellman C. H., Kerp H. \& Hass H. 2006. — Spores of the Rhynie chert plant Aglaophyton (Rhynia) major (Kidston and Lang) D.S Edwards, 1986. Review of Palaeobotany and Palynology 142: 229-250. 